\title{
Models of healthcare for older people
}

\section{Pitkälä, Kaisu}

Oxford University Press

2017

Pitkälä , K , Gladman , J \& Connolly , M 2017 , Models of healthcare for older people . in J-P Michel , B L Beattie , F C Martin \& J D Walston (eds), Oxford Textbook of Geriatric Medicine . 3rd ed. edn , Oxford University Press , pp. 143-152 . https://doi.org/10.1093/med/9780198701590.003.0019

http://hdl.handle.net/10138/310975

https://doi.org/10.1093/med/9780198701590.003.0019

unspecified

acceptedVersion

Downloaded from Helda, University of Helsinki institutional repository.

This is an electronic reprint of the original article.

This reprint may differ from the original in pagination and typographic detail.

Please cite the original version. 


\section{Models of health care for older people}

Kaisu Pitkala, John Gladman, Martin Connolly

\begin{tabular}{|c|c|c|c|c|}
\hline $\begin{array}{l}\text { Kaisu } \\
\text { Pitkala }\end{array}$ & Prof & kaisu.pitkala@helsinki.fi & $\begin{array}{l}+358-50- \\
3385546\end{array}$ & $\begin{array}{l}\text { University of Helsinki, } \\
\text { Department of } \\
\text { General Practice and } \\
\text { Primary Health Care, } \\
\text { PO Box 20, FIN-00014 } \\
\text { University of Helsinki, } \\
\text { Finland }\end{array}$ \\
\hline $\begin{array}{l}\text { John R. F. } \\
\text { Gladman }\end{array}$ & Prof & John.Gladman@nottingham.ac.uk & $\begin{array}{l}(+44) 0115 \\
8230242\end{array}$ & $\begin{array}{l}\text { Division of } \\
\text { Rehabilitation and } \\
\text { Ageing, School of } \\
\text { M edicine \& } \\
\text { M RC/ Arthritis } \\
\text { Research UK Centre } \\
\text { for M usculoskeletal } \\
\text { Ageing Research, } \\
\text { Division of } \\
\text { Rehabilitation and } \\
\text { Ageing, B Floor } \\
\text { Medical School, } \\
\text { Queen's M edical } \\
\text { Centre, Nottingham, } \\
\text { NG7 2UH, UK }\end{array}$ \\
\hline $\begin{array}{l}\text { Martin } \\
\text { Connolly }\end{array}$ & Prof & martin.connolly@waitematadhb.govt.nz & & $\begin{array}{l}\text { University Department } \\
\text { of Geriatric M edicine, } \\
\text { Waitemata District } \\
\text { Health Board, Po Box } \\
93 \text { 503, Takapuna, } \\
\text { Auckland, New } \\
\text { Zealand }\end{array}$ \\
\hline
\end{tabular}




\begin{abstract}
Older people are major users of health and social care in many developed countries, and so all health and social care systems in such countries need to be fit for older users such as those with deafness, blindness or dementia. Despite this, specific services for older people with the most complex or challenging problems have developed. These models of health care for older people are diverse. They can deal with both acute and chronic health problems including rehabilitation. They can be provided in or across community, long-stay, and hospital settings. They often involve a wide range of professionals. They have developed in different ways in different countries. This chapter describes specific models of older people's care, and outlines the role of geriatricians and other professionals in the models.
\end{abstract}

\title{
KEYWORDS: Comprehensive geriatric assessment, CGA, hospital models of geriatrics care, geriatric services, community models of geriatrics care, long-term geriatrics care,
}

\section{Development and rationale for geriatric medicine}

\subsection{History}

The development of geriatric medicine has been widely credited to Dr Marjorie Warren who worked in the West Middlesex Hospital, United Kingdom in 1940s, rehabilitating old bedbound patients. Her work inspired other pioneers to take up this new specialty and to develop rehabilitation. This "traditional model of geriatrics" took place mainly in long stay hospitals rather than general hospitals. However, gradually geriatricians started to gain more influence over the acute care of older patients in general 
hospitals. Since the 1970s three models have emerged for the acute hospital care of older people in the UK. In the "integrated model", geriatricians worked alongside other general physicians with other specialty interests, sharing the medical admitting wards. In the "age specific" model, geriatricians and their teams provided a parallel acute medical service for patients over a given age (often 75), while all the other general physicians provided a service for those beneath that age. In the third model there was also a parallel service run by geriatricians and their teams, but based on needs rather than age - the "needs-related" service. By the end of the $20^{\text {th }}$ century, geriatric medicine had become by far the largest acute hospital medical specialty in the UK. In the early $21^{\text {st }}$ century, the relentless reductions in acute hospital lengths of stay prompted two further developments: an increasing focus on short term acute care in acute medical assessment units in hospital, and tentative exploration of community geriatrics.

Many other countries such as Australia have taken a similar path to the UK in terms of the development of geriatric medicine as a dominant internal medical specialty. It is an independent specialty in many European countries, or a subspecialty requiring a primary specialty, usually internal medicine. In this approach, as in the UK, geriatric medicine is a hospital-based and secondary care specialty involving acute geriatric and rehabilitation wards, and out-patient clinics.

But geriatric medicine has not developed into a predominantly hospital-based specialty in all countries. In the US, geriatrics was initially restricted in the 1960s to nursing home practice, and there was ambiguity about whether it should be developed in primary care or become a secondary care specialty, and it has remained a relatively small discipline (although the creation of the National Institute of Aging led to extensive research funding in this field for a number of randomised, controlled trials to test geriatric models of care). Some countries, however, have developed geriatric medicine models of care in primary care (Canada, Finland) and others have done so particularly in nursing homes (France, and the 
Netherlands, where it has developed here separately from the smaller hospital based geriatrics).

However, even in some developed countries with substantial older populations, such as Greece and Portugal, geriatric medicine has barely developed, and the care of older people falls to community doctors, internal medicine specialists, and a range of other specialists in neurology and physical medicine and rehabilitation.

The highest numbers of specialists are found in Austria, Finland and Sweden (about 400-1000 people aged $>80$ / geriatrician in 2011). In the UK the respective figure was about 4200 people aged $>80$ / geriatrician but numbers have increased since then.. The number of geriatricians affects the feasibility of different models of care. The smaller the number of geriatricians, the more they need to work in models that focus on the most complex patients who are most in need of their skills, or in the training of others. As their numbers increase in the workforce, they can take responsibility for a wider range of patients. But given the demographic changes seen in most countries, and the increasing domination of both the hospital population and primary care workload by older people, there is surely an argument that frailty care is everybody's business and, hence, that all staff irrespective of specialty should be trained in frailty care and that all models of care should be based on the principles of geriatric medicine.

These principles of geriatric medicine have become clear irrespective of the way geriatric medicine developed. 
.BOX 1 Principles of the comprehensive geriatric assessment (CGA) process

- patients should receive an individualized, comprehensive assessment of their health, function and resources (personal, social and environmental)

patient-centred objectives of care and a management plan should be based upon this assessment; the patient and/or their family if the patient is not competent should be involved in decision making

there should be the co-ordination of implementation of the management plan, usually by a multidisciplinary team, with regular review of the patients' progress 


\section{The place of models of geriatrics in population health care}

We have described how specific services for older people, and the principles behind them, developed empirically. More recently, the complexity of the organisation of health care for older people has been considered more systematically and theoretically. Figure 1 illustrates that the older populations comprises a wide diversity of people and needs. There is large proportion of relatively fit older people, but many have one or more long term conditions or frailty, some are complex and some are very complex. As the needs of these groups vary, so too does the service required to meet these needs. Generic, primary care services tend to deal with the majority of older people with few or uncomplicated needs or long term conditions. Specialist services and facilities such as hospitals and long term care facilities tend to deal with the most complex patients. Inevitably, there is some potential overlap between the groups illustrated in Figure 1, and uncertainty about which is the best service model for each group. We describe in the next sections some of the specific models of health care for older people.

\section{Figure 1 about here}

\section{Present day specialist models of care for older people}

\subsection{Hospital models of care for older people}

Table 1 shows the various hospital models of care for older people. The acute geriatric ward is the most common model of care and where most geriatricians work, in most countries with well-developed specific services for older people (Pitkala et al. 2015). The acute geriatric ward addresses needs of acutely ill, multi-morbid, frail older patients and those with geriatric syndromes. CGA is the core process that a multi-professional team uses to assess and care these patients. There is a strong evidence 
that this model is highly effective in producing functional benefit compared with conventional hospital, and in increasing the likelihood of living at home after discharge (Baztan et al. 2009) and decreasing mortality (Ellis et al. 2011).

Geriatric medical teams may also provide a consultation service to other specialties in hospital, such as in preoperative assessment. Consultation teams are often small, and a drawback is that there are often limits to the extent that their recommendations are put into practice. This is understood to be why models involving in-patient units implementing CGA and having control over the execution of the management plan are more effective than merely consultation teams, or even peripatetic case-finding teams. Nevertheless, although trials of such teams have not shown benefits in terms of functional outcomes, length of stay or institutionalisation, they have been shown to reduce mortality (Deschodt et al. 2013). The same applies to geriatric outpatient clinics (Stuck et al. 1993). The observation that specialist teams for older people that can put the findings of a comprehensive assessment into practice are more effective than those that cannot put such findings into practice argues for the use of specialist geriatric wards where possible but it also supports the argument that all teams that deal with older people irrespective of specialty should have the motivation, knowledge, skills and resources to deal with frail older people.

Geriatric rehabilitation wards are the second most common geriatric model where geriatricians work in Europe and USA, and in some counties (e.g. New Zealand), are the commonest model. These wards may be intermediate care facilities where acutely ill older patients are admitted after their acute problems are resolved in other inpatient units or they may be specialised units for stroke rehabilitation or hip fracture patients. Stroke rehabilitation units (Stroke Unit Trialists Collaboration 2013) have shown strong evidence for improving patient outcomes. Both general geriatric rehabilitation and orthopaedic 
geriatric rehabilitation improve functional outcome, and reduce nursing home admissions, and their combined effect also show lower mortality (Bachmann et al. 2010).

Details of the clinical and operational aspects and the evidence for effectiveness of these various services can be found in a range of other chapters in this book (eg CGA chapter 017: Orthogeriatrics, Chapter 79: Stroke Units Chapter 120: Acute frailty units Chapter 143)

\section{Table 1 about here}

New models of outpatient clinics for older people are evolving such as falls prevention clinics, acute stroke/TIA clinics, outpatient clinics focusing on the diagnosis and management of dementia, frailty clinics, or outpatient clinics for older patients with polypharmacy.

There are models of shared care where geriatricians and specialist teams for older people work alongside other specialties. Few randomised studies have evaluated orthogeriatric wards. These show shortened length of stay (Grigoryan et al. 2014) but generally not changed health outcomes. There are various approaches to orthopaedic and geriatrics collaboration with probably different benefits, asdiscussed in Chapter 079.

New models of shared care have been created for older multi-morbid patients with mental health problems or with geriatricians consulting in emergency departments or intensive care units.

\subsection{Community models of geriatric care}

\section{$\underline{\text { Generic community care services }}$}

Services to improve the health and well-being of older people in the community are numerous and comprise both generic and specific services. The health and well-being of older people is affected by 
generic health and social care services for people of all ages such as educational attainment, housing, income levels, public health interventions (e.g. reducing smoking and alcohol use, vaccination, food hygiene, etc.), and access and quality of primary health care. Many older people suffer from disabilities, and so their health and well-being will also be affected by generic services providing social support from formal social care services (for example, home care), the voluntary sector (for example, information and advocacy) and civic society (for example, support from family in existing or retirement communities). Many older people also suffer from social disadvantages, and their health and well-being benefits from generic services to alleviate these problems (for example, support groups for those who are lonely, or welfare payments for those in poverty). Although this chapter focuses on specific models of health care for older people, it is important not to underestimate the significance of generic factors upon the health and well-being of older people. Table 2 shows examples of a variety of community care services.

\section{Table 2 about here}

Even amongst these generic services, for the more complex groups of patients (who are usually older people) there are complex interventions which largely adhere to the principles that underpin specific geriatric medical services. For example, whereas traditional, task-based home nursing for older people may not be cost-effective, multifactorial, patient-centred models of care show effectiveness in improving functioning, reducing hospital and nursing home admissions (Beswick et al. 2008). Similarly, preventive home visits based around responding to a comprehensive assessment for older people may have some benefits in decreasing mortality although not institutionalisation or hospitalisation (Mayo-Wilson et al. 2014). The findings may be conflicting due to different target groups, interventions, outcomes and follow-up times.

\section{$\underline{\text { Specific community care services }}$}




\section{Day hospital}

One of the oldest community-based specific geriatric model of care is the day hospital. These are units, often on a general hospital site, that enable a specific geriatric multidisciplinary team to deliver the comprehensive geriatric process to patents after, or instead of, a hospital stay. When tested in randomised trials these units showed advantages over the provision of no co-ordinated care, but no advantage over equivalent clinical care offered at home or in an extended hospital ward stay. (Forster et al. 2008). The inconvenience and cost of transporting increasingly frail patients to and from day hospitals, increasing patient preference for and provision of home based care, and increasing pressure on the estates of general hospitals has limited the degree to which this model of care developed and it has declined in UK in recent years.

\section{Hospital at home}

In many countries where geriatric rehabilitation developed as hospital based specialty, patients were admitted to hospital for rehabilitation. But in recent decades rehabilitation services have been provided in the community, and in some countries this has given them the name "hospital at home" because they were seen as replacing what would otherwise have been hospital care. As the capacity in the community to deliver the complex process of rehabilitation was shown to be feasible, services for patients with increasing levels of acuity developed. The more such services are in place, the more it has become usual

for many conditions to be managed in community settings, and so increasingly terms such as community rehabilitation or intermediate care are more commonly used to describe them. Intermediate care services are now described in terms of their service functions either to prevent hospital admissions or to expedite earlier discharge from hospitals, or in terms of the community based setting in which they are delivered which can either be in the patient's own home or a sub-acute facility. 
Rehabilitation has been increasingly delivered in people's homes to expedite earlier discharge from hospital for stroke, hip fracture and older patients in general. While there is a potential that home-based rehabilitation might be better tailored to patient's needs there is still insufficient evidence to argue that outcomes are superior to alternative strategies. However, the evidence that patients are more satisfied with such services and that they can reduce the length of hospital stay has made them increasingly popular in many health care systems (Shepperd et al. 2009).

Hospital-avoidance intermediate care services, often providing a mixture of acute medical care either in isolation (e.g. during acute exacerbation of COPD) or alongside rehabilitation also have some evidence of benefit. End of life care incorporating palliative approaches has much in common with the process of comprehensive geriatric assessment, and the majority of those in receipts of such care are older people. Services that are specific variants of the hospital at home service model have developed to support patients receiving terminal care wishing to die at home, and the trial evidence shows that they are more successful than usual care in enabling them to do so.

\section{Dementia care}

Dementia case managers work in cooperation with caregivers and other professionals. They are specialised in dementia, work in a patient-centred way, and consult GPs or geriatricians. Skilled dementia case managers show evidence in postponing institutional care and improving caregivers' quality-of-life (Reilly et al. 2015).

\section{Other models for management of long term conditions}

Various chronic care models, either care managers specialized in single disease or professionals specialised in secondary prevention of various chronic diseases have shown efficacy in improving health 
of chronically ill older people (Chodosh et al. 2005). These care models rely often on interventions that promote self-management, such as helping patients and their caregivers to identify their problems, developing their own problem-solving skills and improving their self-efficacy in mastering their everyday life.

\subsection{Long term care facilities}

About $4 \%$ of people $65+$ in many European countries (e.g. France, Finland, UK) and the U.S. reside in various types of care homes (Briggs et al. 2012). However this figure, which represents care home use at any single point in time, grossly underestimates likelihood lifetime use by an older person - which in some counties approaches half for those living beyond the age of 65 years.

The terms "care home", "nursing home" and "residential home" may mean different things in different countries. In most countries, the terms nursing or residential homes are used to describe long-term facilities, but in some countries such homes offer subacute care, rehabilitation, other hospital, or hospice care. An international definition of "nursing home" has been proposed (Sanford et al, 2015). Long term care facilities may provide varying levels of medical, nursing, and support services: those with more intense provision are more like hospitals, and those with lower levels of provision may be termed assisted living facilities. Some have more communal and institutional aspects to them akin to a hospital ward, whereas others are little more than a collection of independent units in close proximity. The environmental ethos too may vary from facilities modelled around a medical, hospital-style of care (such as the use of regimented institutional practices and clinically functional equipment and furnishings), to those where the facility is primarily the resident's home (such as where residents may have their own furnishings, pets, and routines). Models of health care for long term care facilities will vary according the type of facility and the nature of its residents. Table 3 describes various names and types of housing and long-term care facilities available for older people. 


\section{Table 3 about here}

Traditional nursing home beds have either declined or remained static in number for two decades, even though the number of old people is increasing in developed countries. This is because there is increasing provision of domiciliary care - the consequence is that, over time, the residents of nursing homes are becoming more disabled and complex, particularly providing care for people with the later stages of dementia. It is somewhat paradoxical that just as the residents have become more like patients who would previously have been cared for in hospital, the trend has generally been away from hospital-like institutions towards more homely ones, a change of emphasis that has been associated with a presumption that the care residents require is social care rather than health care. This has influenced the context in which health care for residents of long term care facilities have been planned and developed.

In most developed countries long-term care facilities are nowadays managed by nurses or administrators who may or may not be health care professionals. The staff working in nursing homes may include a large proportion of people not qualified in health care, nor with any specific training related to the challenges faced by older people with frailty. In many countries there is an infrequent presence of physicians in long term care facilities. In most countries generic general practitioners provide medical input to residents, with few incentives to provide a specific service for long term care facilities. In the absence of specific models of health care for older people in long term care facilities, standards and quality of care are highly variable between as well as within countries (Briggs et al. 2012). There is an emerging research agenda that addresses the complex interplay of health and social care challenges in long term care (Morley et al, 2014).

There are concerns especially about inappropriate prescribing, inadequate access to rehabilitation professionals, and inappropriate admission to hospital for terminal care. Legislation plays a part: in the 
US the Omnibus Budget Reconciliation Act (OBRA) included guidelines for the use of antipsychotics and physical restraints, and created nursing home resident bill of rights. It also mandated the creation of a comprehensive assessment called the Resident Assessment Instrument (RAI) which led to the development of the minimum data set (MDS) which is now widely used across the world to assess quality of care and drive the delivery of residents' care plans. (Bernabei et al. 2008)

Some specific health care models for long term care facilities have developed as alternatives to the provision of undifferentiated primary care. In the US and the Netherlands there are well developed care home medicine specialties, where the health care process is led by a specialist in the field rather than a generic primary care physician. Developments in the UK illustrate the potential range and variety of other models, particularly those aimed at augmenting generic primary care, such as the use of specialist advance nurse practitioners to provide primary care to the residents of long term care facilities, groups of general practitioners dedicated solely to serving these facilities, hospital outreach by community geriatricians, and a range of specific services and teams for care home facilities. Unlike the models of care developed for hospitals, the evidence base for the benefits of these models of care is sparse. Care homes are discussed in more detail in Chapter 039.

\section{Implementation of specific services for older people}

The structure of geriatric services has developed over six decades during which a shortage of a knowledgeable and skilled work force has affected the extent to which they have been implemented despite the growing evidence of the effectiveness of some of the service models (Reuben et al. 2003). Nevertheless, nowadays, a specialist model of care delivering the comprehensive geriatric assessment process in hospital setting is widely implemented (where the evidence is strongest) but in most countries the limited number of geriatricians (and the weaker evidence base) has restricted them from working in 
community care or long term care facilities, where the presence of the comprehensive geriatric assessment process is limited. In a survey of geriatricians in 19 countries, $44 \%$ stated that CGA is poorly implemented in their country (Pitkala et al. 2015). The biggest problems were a lack of knowledge of geriatric medicine in the workforce and a lack of geriatricians. Patient-centred approaches and interdisciplinary team working are part of generic primary care practice in the community or in long term care facilities, but often the services in these settings lack input from a geriatrician.

It should not be assumed that the solution for services to community or long term care facilities should simply aim to apply a hospital-based model to deliver the comprehensive geriatric assessment process in these settings. Indeed, certain ways of working in these settings are likely to have much from which hospital services can benefit. For example, the RAI process developed in long term care settings provides a clear, reproducible, systematic and objective structure to care, and a similar approach might also improve the delivery of the comprehensive geriatric assessment process in hospitals. The empowerment of older patients and their caregivers that is typified by self-management models in primary health care and in social care, and may be detrimentally overridden in acute hospital and longterm care setting. Continuity of care is implemented at its best in the practice of primary care physicians and nurse practitioners practice who have responsibility for the management of long term conditions, but is difficult to achieve in hospital models of care.

\subsection{Future prospects}

Geriatric models of care are evolving and flourishing. The knowledge and skills about the care of older people of other professionals is improving. Generic health services and sociality in general are becoming more suitable for older patients and citizens. Nevertheless, all professionals within gerontology and geriatrics still have an important role in continuing to develop specialist knowledge, disseminating it, 
and supporting the organisation of services that puts this knowledge into practice. There is much still to do, even in developed countries. This requires attention to interdisciplinary cooperation, academic research, education and training, and influencing policy to improve older people's care. 


\section{References: (26)}

Bachmann, S., Finger, C., Huss, A., Egger, M., Stuck, A.E., Clough-Gorr, K.M. (2010). Inpatient rehabilitation specifically designed for geriatric patients: systematic review and meta-analysis of randomised controlled trials. BMJ, 340, c1718

Baztán, J.J., Suárez-García, F.M., López-Arrieta, J., Rodríguez-Mañas, L., Rodríguez-Artalejo, F. (2009) Effectiveness of acute geriatric units on functional decline, living at home, and case fatality among older patients admitted to hospital for acute medical disorders: meta-analysis. BMJ, 338, b50

Bernabei, R., Landi, F., Onder, G., Liperoti, R., Gambassi, G. (2008). Second and third generation assessment instruments: the birth of standardization in geriatric care. J Gerontol A Biol Sci Med Sci, 63, $308-13$

Beswick, A.D., Rees, K., Dieppe, P., et al. (2008). Complex interventions to improve physical function and maintain independent living in elderly people: a systematic review and meta-analysis. Lancet, 371, 725-35

Briggs, R., Robinson, S., Martin, F., O'Neill, D. (2012). Standards of medical care for nursing home residents in Europe. Eur Geriatr Med, 3, 365-7

Chien, L.Y., Chu, H., Guo, J.L. et al. (2011). Caregiver support groups in patients with dementia: a meta-analysis. Int J Geriatr Psychiatry, 26, 1089-98

Chodosh, J., Morton, S.C., Mojica, W., et al. (2005). Meta-analysis: chronic disease self-management programs for older adults. Ann Intern Med, 143, 427-38 
Deschodt, M., Flamaing, J., Haentjens, P., Boonen, S., Milisen, K. (2013). Impact of geriatric consultation teams on clinical outcome in acute hospitals: a systematic review and meta-analysis. $B M C$ Med, 11, 48

Dickens, A.P., Richards, S.H., Greaves, C.J., Campbell, J.L. (2011). Interventions targeting social isolation in older people: a systematic review. BMC Public Health, 11, 647

Ellis, G., Whitehead, M.A,, Robinson, D., O'Neill, D., Langhorne, P. (2011). Comprehensive geriatric assessment for older adults admitted to hospital: meta-analysis of randomised controlled trials. $B M J$, 343, d6553

Forster, A., Young, J., Lambley, R., Langhorne, P. (2008). Medical day hospital care for the elderly versus alternative forms of care. Cochrane Database Syst Rev, 4, CD001730

Grigoryan, K.V., Javedan, H., Rudolph, J.L. (2014). Orthogeriatric care models and outcomes in hip fracture patients: a systematic review and meta-analysis. J Orthop Trauma, 28: e49-55

Jensen, M., Agbata, I.N., Canavan, M., McCarthy, G. (2015). Effectiveness of educational interventions for informal caregivers of individuals with dementia residing in the community: systematic review and meta-analysis of randomised controlled trials. Int J Geriatr Psychiatry, 30, 130-43

Mason, A., Weatherly, H., Spilsbury, K., et al. (2007). The effectiveness and cost-effectiveness of respite for caregivers of frail older people. J Am Geriatr Soc, 55, 290-9

Mayo-Wilson, E., Grant, S., Burton, J., Parsons, A., Underhill, K., Montgomery, P. (2014). Preventive home visits for mortality, morbidity, and institutionalization in older adults: a systematic review and meta-analysis. PLoS One, 9, e89257 
Morley JE, Caplan G), Cesari M et al. International survey of nursing home research priorities. J Am Med Dir Assoc. 2014 May;15(5):309-12. doi: 10.1016/j.jamda.2014.03.003. Epub2014 Apr 3

Pitkala KH, Jyvakorpi S, Strandberg TE. Survey on geriatrics in 19 countries. Eur Geriatr Med, 2015.

Reilly, S., Miranda-Castillo, C., Malouf, R., et al. (2015). Case management approaches to home support for people with dementia. Cochrane Database Syst Rev, 1, CD008345.

Reuben, D.B., Shekelle, P.G., Wenger, N.S. (2003). Quality of care for older persons at the dawn of the third millennium. J Am Geriatr Soc, 51, S346-S50

Sanford AM, Orrell M, Tolson D, et al. An international definition for "nursing home". J Am Med Dir Assoc. 2015 Mar;16(3):181-4. doi: 10.1016/j.jamda.2014.12.013. PubMed PMID: 25704126.

Shepperd, S., Doll, H., Broad, J., et al. (2009). Early discharge hospital at home. Cochrane Database Syst Rev, 1, CD000356

Shepperd, S., Wee, B., Straus, S.E. (2011) Hospital at home: home-based end of life care. Cochrane Database Syst Rev, 7, CD009231

Stroke Unit Trialists' Collaboration. (2013). Organised inpatient (stroke unit) care for stroke. Cochrane Database Syst Rev, 9, CD000197

Stuck, A.E., Siu, A.L., Wieland, G.D., Adams, J., Rubenstein, L.Z. (1993). Comprehensive geriatric assessment: a meta-analysis of controlled trials. Lancet, 342, 1032-6

Weissert, W.G., Cready, C.M., Pawelak, J.E. (1988). The past and future of home- and communitybased long-term care. Milbank Q, 66, 309-88

Warren M. Modern care of older people. Lancet 1947;i: 761 
Figure 1. Heterogeneous older populations: their health needs, models of care and their managing professionals according to these segments of population.

\section{Characteristics of population segment}

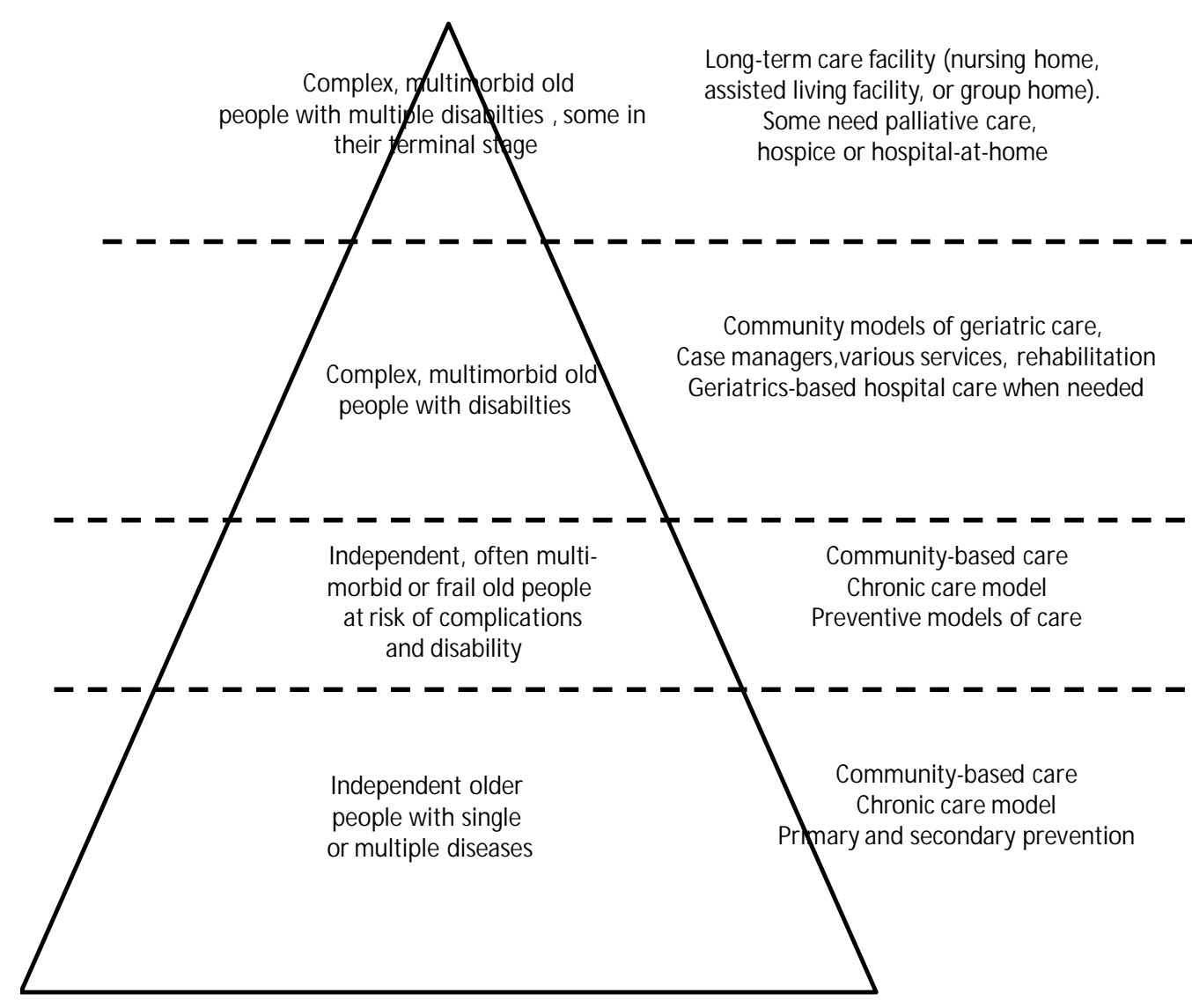

Health needs

Rehabilitation, maintainance of functioning, nutrition

symptom control

\section{Management of care}

Gerontological nurse as leader of team physician (GP or geriatrician) specialised

in long-term care as part of team.

In terminal care physician leading the team
Often geriatric syndromes,

complex and multidimentiona needs, tailored interventions rehabilitation

In community care nurse practitioner with a physician specialised in community-based long-term care (GP or geriatrcian). People with dementia or specfic syndromes may benefit from case managers. In geriatric hospitals and subacute rehabilitation geriatricians lead interdiciplinary teams specialized in geriatrics

Good care of chronic diseases, Nurse practitioners, GPs having knowledge secondary prevention of frailty, of frailty, prevention of geriatric syndromes geriatric syndromes and disabilities

Primary - secondary prevention of risk factors and diseases, good care of chronic diseases
Nurse practitioners, GPs with special focus on prevention and continuity of care 


\begin{tabular}{|c|c|c|c|c|c|c|}
\hline $\begin{array}{l}\text { Acute } \\
\text { geriatrics } \\
\text { ward }\end{array}$ & $\begin{array}{l}\text { Acutely ill, often } \\
\text { multi-morbid } \\
\text { older patients }\end{array}$ & $\begin{array}{l}\text { Multi-professional } \\
\text { team (geriatrician, } \\
\text { nurses specialized } \\
\text { in geriatrics, } \\
\text { physical therapists, } \\
\text { social worker, } \\
\text { occupational } \\
\text { therapist, etc.) }\end{array}$ & $\begin{array}{l}\text { Comprehensiv } \\
\text { e geriatric } \\
\text { assessment } \\
\text { (CGA), care } \\
\text { and } \\
\text { rehabilitation }\end{array}$ & $\begin{array}{l}\text { Strong evidence } \\
\text { from RCTs that } \\
\text { geriatric ward } \\
\text { lowers probability } \\
\text { for dependence, } \\
\text { mortality and } \\
\text { institutional care. }\end{array}$ & $\begin{array}{l}\text { Geriatricians concentrate on } \\
\text { acute illnesses. Geriatricians } \\
\text { do not follow up their patients } \\
\text { and continuity of care may be } \\
\text { compromised. Geriatrics } \\
\text { expertise is not incorporated } \\
\text { into prevention and may not be } \\
\text { transmitted to community care. }\end{array}$ & $\begin{array}{l}\text { In most } \\
\text { European } \\
\text { countries and } \\
\text { USA the } \\
\text { primary } \\
\text { working } \\
\text { position for } \\
\text { geriatricians. }\end{array}$ \\
\hline $\begin{array}{l}\text { Geriatrics } \\
\text { consultation } \\
\text { teams in } \\
\text { acute } \\
\text { hospitals }\end{array}$ & $\begin{array}{l}\text { Acutely ill, often } \\
\text { multi-morbid } \\
\text { older patients. }\end{array}$ & $\begin{array}{l}\text { Multi-professional } \\
\text { team, often smaller } \\
\text { than in an acute } \\
\text { geriatric ward. }\end{array}$ & $\begin{array}{l}\text { The team } \\
\text { consults other } \\
\text { units } \\
\text { responsible for } \\
\text { an older } \\
\text { patient, gives } \\
\text { recommendati } \\
\text { ons of care. } \\
\end{array}$ & $\begin{array}{l}\text { Evidence for } \\
\text { effectiveness on } \\
\text { older patients' } \\
\text { mortality but not } \\
\text { on functional } \\
\text { status, or length } \\
\text { of stay. }\end{array}$ & $\begin{array}{l}\text { Geriatrics teams do not have } \\
\text { control over how their } \\
\text { recommendations are } \\
\text { implemented. Geriatrics teams } \\
\text { are often small and their } \\
\text { authority insufficient. }\end{array}$ & $\begin{array}{l}\text { Common model } \\
\text { of care in many } \\
\text { countries. This } \\
\text { model is often } \\
\text { used in } \\
\text { consulting e.g. } \\
\text { surgery } \\
\text { patients. }\end{array}$ \\
\hline Geriatric & Multi-morbid & Multi-professional & CGA, care and & Evidence for & In wards that do not take & In most \\
\hline
\end{tabular}




\begin{tabular}{|c|c|c|c|c|c|c|}
\hline $\begin{array}{l}\text { rehabilitation } \\
\text { wards }\end{array}$ & $\begin{array}{l}\text { older people, } \\
\text { stroke patients, } \\
\text { hip fracture } \\
\text { patients }\end{array}$ & $\begin{array}{l}\text { team often with } \\
\text { consultants form } \\
\text { other specialties }\end{array}$ & rehabilitation & $\begin{array}{l}\text { stroke units, hip } \\
\text { fracture and } \\
\text { rehabilitation } \\
\text { wards that } \\
\text { specialist ward } \\
\text { lowers probability } \\
\text { for dependence, } \\
\text { mortality and } \\
\text { institutional care. }\end{array}$ & $\begin{array}{l}\text { patients immediately when } \\
\text { admitted to hospital, } \\
\text { opportunities to have improved } \\
\text { their health earlier or to have } \\
\text { halted the extent of decline may } \\
\text { have been missed. }\end{array}$ & $\begin{array}{l}\text { European } \\
\text { countries and } \\
\text { USA the second } \\
\text { most common } \\
\text { workplace for } \\
\text { geriatricians. }\end{array}$ \\
\hline $\begin{array}{l}\text { Orthogeriatri } \\
\text { cs ward }\end{array}$ & $\begin{array}{l}\text { Hip fracture } \\
\text { patients, other } \\
\text { fracture patients, } \\
\text { patients in joint } \\
\text { operations }\end{array}$ & $\begin{array}{l}\text { Shared care of } \\
\text { orthopaedic team } \\
\text { with geriatric } \\
\text { expertise or teams } \\
\text { incorporated in hip } \\
\text { fracture } \\
\text { rehabilitation ward. }\end{array}$ & $\begin{array}{l}\text { CGA, pre- and } \\
\text { postoperative } \\
\text { care, operation } \\
\text { and } \\
\text { rehabilitation }\end{array}$ & $\begin{array}{l}\text { Evidence that } \\
\text { shared care wards } \\
\text { may shorten the } \\
\text { length of stay for } \\
\text { hip fracture. }\end{array}$ & $\begin{array}{l}\text { Geriatric knowledge is needed } \\
\text { both pre- and postoperatively. } \\
\text { Efficacy may depend on } \\
\text { multiple factors including } \\
\text { cooperation between geriatrics } \\
\text { and orthopaedics teams and } \\
\text { management strategies. }\end{array}$ & $\begin{array}{l}\text { In most } \\
\text { countries these } \\
\text { models exist but } \\
\text { geriatrics teams } \\
\text { incorporated } \\
\text { with } \\
\text { orthopaedic } \\
\text { teams are not } \\
\text { common. }\end{array}$ \\
\hline $\begin{array}{l}\text { Geriatrician } \\
\text { in emergency } \\
\text { department } \\
\text { (ED) or in } \\
\text { intensive } \\
\text { care unit }\end{array}$ & $\begin{array}{l}\text { Acutely and } \\
\text { seriously ill older } \\
\text { patients }\end{array}$ & $\begin{array}{l}\text { Geriatrician as part } \\
\text { of an acute ED } \\
\text { team }\end{array}$ & $\begin{array}{l}\text { Comprehensiv } \\
\text { e geriatric } \\
\text { approach, } \\
\text { consultation, } \\
\text { management }\end{array}$ & $\begin{array}{l}\text { These models } \\
\text { have not been } \\
\text { systematically } \\
\text { evaluated. }\end{array}$ & $\begin{array}{l}\text { Geriatric knowledge is needed } \\
\text { in front line. More and more } \\
\text { older patients receive intensive } \\
\text { care. The effectiveness of this } \\
\text { model needs evaluation. }\end{array}$ & $\begin{array}{l}\text { Geriatricians in } \\
\text { EDs or } \\
\text { intensive care } \\
\text { units are not } \\
\text { common. }\end{array}$ \\
\hline $\begin{array}{l}\text { Specialised } \\
\text { wards for } \\
\text { multi-morbid } \\
\text { patients with } \\
\text { mental health } \\
\text { problems }\end{array}$ & $\begin{array}{l}\text { Psychiatric } \\
\text { patients with } \\
\text { comorbidities } \\
\text { needing specialist } \\
\text { care }\end{array}$ & $\begin{array}{l}\text { Psychogeriatrician, } \\
\text { geriatrician, } \\
\text { geriatric multi- } \\
\text { professional team } \\
\text { including also } \\
\text { psychiatric nurses, } \\
\text { psychologists etc. }\end{array}$ & $\begin{array}{l}\text { Comprehensiv } \\
\text { e care of multi- } \\
\text { morbid, older } \\
\text { psychiatric } \\
\text { patients }\end{array}$ & $\begin{array}{l}\text { These models of } \\
\text { have not been } \\
\text { systematically } \\
\text { evaluated. }\end{array}$ & $\begin{array}{l}\text { Geriatric knowledge is needed } \\
\text { managing these patients. } \\
\text { Especially multi-morbid } \\
\text { patients with dementia might } \\
\text { benefit from this model. The } \\
\text { effectiveness of this model } \\
\text { needs evaluation. }\end{array}$ & $\begin{array}{l}\text { An emerging } \\
\text { model, but } \\
\text { psychogeriatrics } \\
\text { is not an } \\
\text { independent } \\
\text { specialty in } \\
\text { many countries. }\end{array}$ \\
\hline
\end{tabular}


Table 2. Community services

\begin{tabular}{|c|c|c|c|}
\hline Service & $\begin{array}{l}\text { Professionals developing/ } \\
\text { delivering services }\end{array}$ & Examples & Benefits/ evidence/ future prospects \\
\hline Home care & $\begin{array}{l}\text { Unqualified staff, with } \\
\text { variable training about } \\
\text { social care }\end{array}$ & Assistance in ADL/IADL & \multirow{3}{*}{$\begin{array}{l}\text { Early evidence suggested that rigid } \\
\text { home services not tailored according to } \\
\text { people's needs may not postpone } \\
\text { institutional care nor save health care } \\
\text { costs (Weissert et al. 1988), but may } \\
\text { make life more manageable. }\end{array}$} \\
\hline Meals-on-wheals & Food service staff & Ready-made meals delivered home & \\
\hline Transportation services & Transportation staff & $\begin{array}{l}\text { Taxi services to support inclusion of older } \\
\text { people in society: e.g. recreational activities }\end{array}$ & \\
\hline $\begin{array}{l}\text { Home repair and home } \\
\text { adaptation programs }\end{array}$ & $\begin{array}{l}\text { OTs, architects, } \\
\text { physiotherapists }\end{array}$ & $\begin{array}{l}\text { Removal of doorsteps, slips, handles, } \\
\text { adapted houseware and cutlery etc. }\end{array}$ & $\begin{array}{l}\text { This field develops very rapidly } \\
\text { according to consumers' demands. } \\
\text { Adoption of technology depends on } \\
\text { values, perceived benefits, training, } \\
\text { accessibility, costs, etc. }\end{array}$ \\
\hline Day care & $\begin{array}{l}\text { Unqualified staff, with } \\
\text { variable training about } \\
\text { social care, , may have some } \\
\text { health or social care } \\
\text { professionals }\end{array}$ & $\begin{array}{l}\text { Some models are specialized on mentally or } \\
\text { cognitively impaired. Day care provides } \\
\text { e.g. recreational activities for people with } \\
\text { dementia giving respite for carers. }\end{array}$ & $\begin{array}{l}\text { Day care is associated with carer } \\
\text { satisfaction but it may not be cost } \\
\text { saving (Mason et al. 2007). }\end{array}$ \\
\hline Respite care & Often non health staff & $\begin{array}{l}\text { May be short-term, some hours/day in- } \\
\text { home respite or can be arranged as short- } \\
\text { term periods in institutional settings. }\end{array}$ & $\begin{array}{l}\text { Respite may have positive effects for } \\
\text { carers but it remains underutilised. } \\
\text { Many carers feel they cannot leave } \\
\text { their care to other people. }\end{array}$ \\
\hline \multicolumn{4}{|c|}{ Community-based health care services } \\
\hline Home nursing & Registered nurses & Wound care, medication delivery etc & See box above (home care) \\
\hline
\end{tabular}




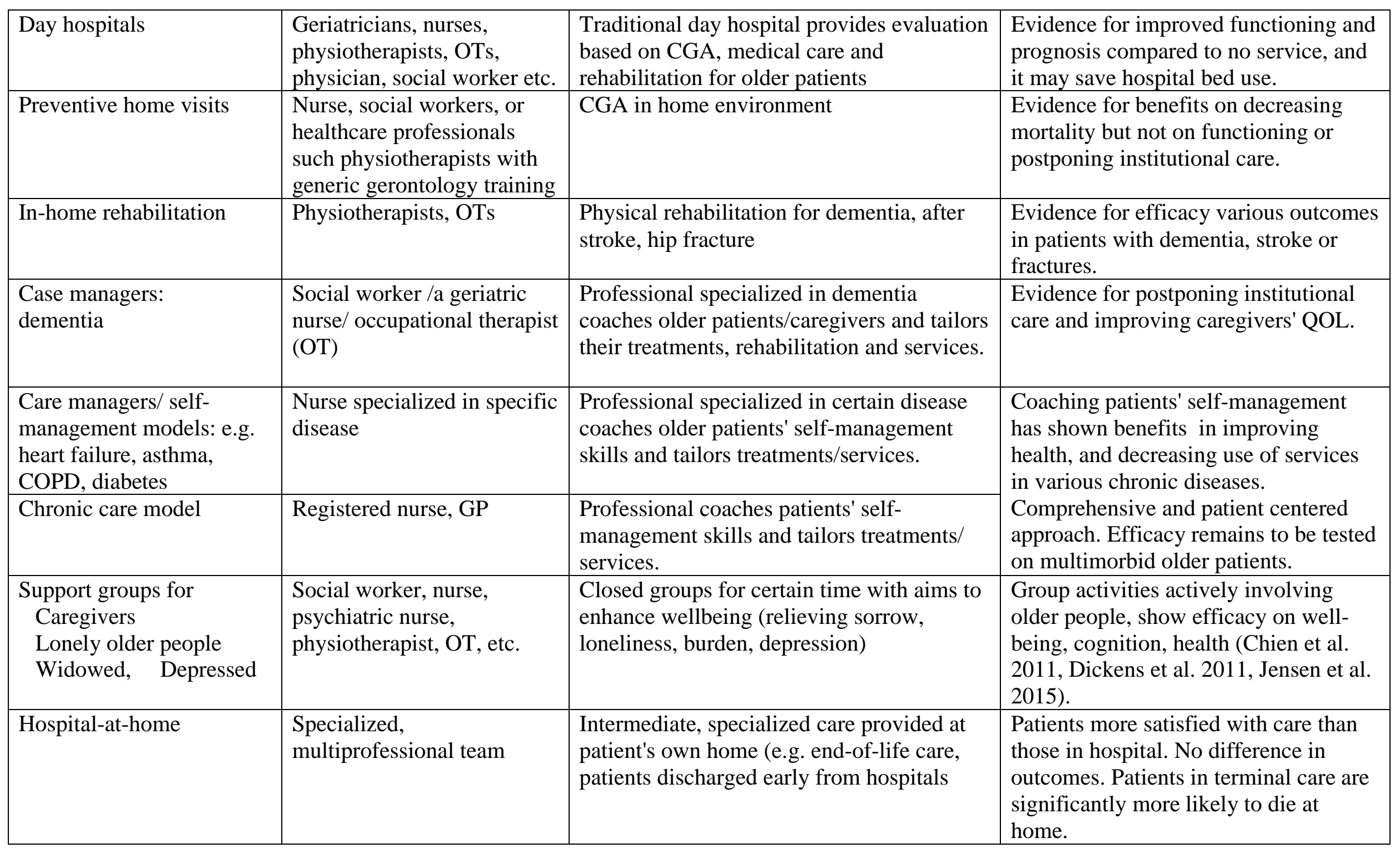


Table 3. Types of housing and long-term care facility models available for older people

\begin{tabular}{|l|l|}
\hline Care model & Definition \\
\hline Retirement villages & $\begin{array}{l}\text { Designed communities for retired older people, an age-friendly place to live where } \\
\text { older people meet people of their own age and help each other. }\end{array}$ \\
\hline Retirement housing & $\begin{array}{l}\text { Usually a multi-residence housing facility intended for senior citizens consisting of } \\
\text { apartment-style rooms. In-house facilities may include meals, recreation activities, } \\
\text { help for personal care. }\end{array}$ \\
\hline Assisted living facility & $\begin{array}{l}\text { Room and board and varying degrees of assistance with management of medical } \\
\text { conditions and with ADLs in physically or cognitively impaired patients. Similar to } \\
\text { nursing homes in their level of care. }\end{array}$ \\
\hline Group home & $\begin{array}{l}\text { Small group homes available, e.g., for patients with dementia. They may specialize } \\
\text { in people with mental health problems, patients with neuropsychiatric symptoms or } \\
\text { certain ethnic groups. May have 24 hour support available. }\end{array}$ \\
\hline Residential care & $\begin{array}{l}\text { Long-term care given to older people who stay in a residential setting with 24 hour } \\
\text { support rather than in their own home. Various options available depending on the } \\
\text { needs of the individual with disabilities, mental health problems, or dementia. Care } \\
\text { planning and supervision by non health staff }\end{array}$ \\
\hline Nursing home & $\begin{array}{l}\text { Facility providing 24-hour care for people requiring assistance with ADLs/IADLs } \\
\text { and having identified health needs. Nursing care 24 hours }\end{array}$ \\
\hline Long-term care ward & $\begin{array}{l}\text { Usually in a hospital or other mixed use facility. Provides room and board, } \\
\text { management of chronic medical conditions and assistance with ADLs in physically } \\
\text { and/or cognitively impaired patients. More hospital like than traditional nursing } \\
\text { homes. }\end{array}$ \\
\hline
\end{tabular}

